\title{
The Lectin Recognition Hypothesis in Rhizobium-Legume Interactions
}

\author{
根粒菌とマメ科植物の相互作用を説明する"レクチン認識"仮説
}

\author{
Wang, J.L., Schindler, M., and Ho, S.-C. \\ Department of Biochemistry, Michigan State University, East Lansing, MI 48824, USA, FAX: 1-517-353-9334
}

Key Words: bacterial adhesion, carbohydrate recognition, nodulation, Rhizobium, symbiosis

\begin{abstract}
The "lectin recognition" hypothesis was proposed to account for experimentally observed host specificity when members of the Rhizobium genus of soil bacteria infect the roots of leguminous plants, leading to the formation of nodules capable of fixing atmospheric nitrogen. According to this hypothesis, recognition between rhizobia and the legume root involves a binding of the host plant lectin to unique carbohydrates found on the bacterial symbiont. Analyses of the attachment of $R$. leguminosarum biovar trifolii to the white clover root surface have provided support for the hypothesis involving plant-derived lectins and bacterial surface polysaccharides. On the other hand, data accumulated on the Bradyrhizobium japonicum-soybean adhesion system are inconsistent with recognition mediated by the soybean lectin. Although this adhesion system indeed involves saccharide-specific recognition, the experimental data suggest that the lectin actually resides on the bacteria while the plant cell presents the carbohydrate ligand. This notion casts, therefore, a new view of the "lectin recognition" hypothesis.
\end{abstract}

\section{A. Introduction}

Many eukaryotic and microbial cells can recognize and interact specifically with other cells, either cells of the same type (homotypic) or cells of a different type (heterotypic). Our understanding of the molecular components mediating specific recognition has advanced as a result of the isolation and analyses of molecules belonging to families of proteins designated as Cell Adhesion Molecules (CAMs), cadherins, and integrins (1$3)$. In particular, the role of carbohydrate recognition in cell adhesion has been documented for: i) the leukocyte homing receptors belonging to the P-selectin, E-selectin, and L-selectin families (4); ii) mouse sperm-egg interactions, involving $\beta$ 1,4-galactosyltransferase and a galactose (Gal) determinant on the ZP3 receptor, respectively (5); and iii) adherence of pathogenic bacteria, via adhesin molecules, to epithelial cell surfaces (6). A system quite analogous to bacterial adhesion to mamalian epithelia, but with an end result regarded as mutually beneficial to both interacting partners rather than as pathogenic invasion, is the binding of rhizobia to the root cells of leguminous plants, leading to infection, formation of nodules, and a
要 約

土壌細菌の仲間である根粒菌は、マメ科の植物の根に感染 後、根粒を形成して大気中の窒素を固定できるようになる。感 染の際に観察される宿主特異性を説明するために提唱されたの が"レクチン認識"仮説である。(訳者注: 邦文ではレクチン説と 呼ばれることが多いようである)。この仮説によると、根粒菌と マメ科植物の根の間の認識は、宿主の植物のレクチンが共生根 粒菌の糖鎖へ特異的に結合して起こる。クローバー根粒菌 $(\mathrm{R}$. leguminosarum biovar trifolii)のクローバーの根の表面への付着を 調べると、宿主植物由来のレクチンと根粒菌表面の多糖類が関 与しているらしい。一方、ダイズ根粒菌(Bradyrhizobium japonicum)のダイズ根への付着にはダイズレクチンが関与しな いことがわかってきた。この系においても糖鎖の特異的認識が 関係しているのは確かだが、レクチンは宿主植物ではなく根粒 菌に由来し、宿主植物は糖りガンドを提示するのである。つま りこの系では"レクチン認識"仮説が別な視点からとらえられる ことになる。

\section{A. はじめに}

真核細胞や微生物細胞には、他の細胞を認識して特異的な 相互作用を行なうものが多い。相手の細胞は同じタイプ (homotypic) の場合もあれば、異なったタイプ(heterotypic) の場 合もある。細胞接着分子(Cell Adhesion Molecules; CAMs) やカド ヘリン、インテグリン(1-3)蛋白質ファミリーに属する分子の単 離、解析により、特異的認識をつかさどる分子に対する理解が 樑まってきている。特に、細胞接着における糖認識の役割は以 下の例で立証されている。i) P-、E-、L-セレクチンファミリー に属する白血球のホーミングレセプター(4)、ii)マウスの精子と 卵子の相互作用(精子の $\beta-1,4$ - ガラクトース転移酵素と卵子の ZP3 受容体上のガラクトース決定基の関与)(5)、iii) 病原性細菌 の接着分子を介した上皮細胞表面への接着(6)、の3通りの場合 である。根粒菌がマメ科植物の根に結合後、感染して根粒を形 成し窒素固定共生をするという現象はiii)の例と似ているが、病 原性をもつ細菌が一方的に侵入するのに対し、相互作用する両 
nitrogen-fixing symbiosis (7-9).

Rhizobia is a collective term encompassing three genera of gram negative bacteria: Rhizobium, Bradyrhizobium, and Azorhizobium (Table I). Each member of the three classes of rhizobia can nodulate a specific legume: $R$. leguminosarum bv. viciae nodulates pea and vetch; $R$. leguminosarum bv. trifolii (hereafter referred to as $R$. trifolii) nodulates clover; and $B$. japonicum nodulates soybean. This host specificity is observed throughout the nodulation process, including the early stages before infection initiation. It is most likely determined by multiple levels of interactions between components derived from both partners of the symbiosis (8-10).

First, there are diffusible signals from the plant to the bacteria. Rhizobia are chemotactic towards specific flavonoid compounds released by the legume roots $(8,11)$. The flavonoids induce transcription of an important set of nodulation (nod) genes in rhizobia; this process is mediated by $\operatorname{nod} D$, the only nod gene constitutively expressed (12). Nod D proteins from different species of rhizobia recognize different flavonoids preferentially and these activate the transcription of the other nod genes. Thus, this molecular recognition constitutes an important first level determinant of host-Rhizobium specificity $(8-10)$.

Second, there are diffusible signals from the bacterium to the plant. The induction of bacterial nod genes results in the synthesis and secretion of Nod factors. Host specificity here is determined by species-specific chemical modification of the signal molecules. Nod factors secreted by $R$. meliloti, whose preferred host is alfalfa (Table I), and $R$. leguminosarum bv. viciae, which nodulates pea or vetch, are modified $\beta$-1,4-linked oligomers of $N$-acetyl-D-glucosamine $(13,14)$. The sulfate group of the $R$. meliloti factor is an important host specificity determinant (13), whereas the $O$-acetyl group and the nature of the fatty acyl substituent affect the biological activity of the $R$. leguminosarum bv. viciae factors (14). The responses of plant cells to the Nod factors include membrane potential depolariza-
者に利益となるという点で異なる(7-9)。

根粒菌という名はグラム陰性菌に属する3つの属 (Rhizobium 属、Bradyrhizobium属、Azorhizobium属)の総称であ る(表I参照)。この3種はそれぞれ特異的にマメ科の植物に根粒 を作ることができる。エンドウマメ根粒菌(R. leguminosarumbv. viciae) はエンドウマメとソラマメに、クローバー根粒菌(R. leguminosarum bv. trifolii ; 以降R. trifolii と略す) はクローバー に、ダイズ根粒菌(B. japonicum)はダイズに感染できる。この宿 主特異性は感染開始以前の初期段階を含む根粒形成の全過程に おいてみられる。共生においては、宿主植物と根粒菌の双方に 由来する要素が様々なレベルで相互作用して宿主特異性が決ま ると考えられる(8-10)。

まず最初に宿主植物の根から根粒菌に向けてフラボノイド 化合物が拡散してゆき、根粒菌はその信号に対し特異的に走化 性を示す $(8 、 11)$ 。根粒菌は根粒形成(nodulation)に関わるnod 遺 伝子とよばれる一群の重要な遺伝子をもっており、この転写が フラボノイド化合物によって活性化される。この過程はnod D遺 伝子を介しておこなわれる。nod D遺伝子はnod 遺伝子群の中で 唯一構成的に発現している遺伝子である(12)。NodD蛋白質は根 粒菌の種によって異なり、各々異なったフラボノイドと選択的 に結合し、その結果、他のnod 遺伝子の転写が活性化される。 すなわち、フラボノイドとnod 遺伝子の間の分子認識は宿主特 異性決定における重要な第一段階となっている(8-10)。

続いて第二段階として、根粒菌のnod 遺伝子が誘導される とNod因子が合成、分泌され宿主植物に向かって拡散してい く。この段階で宿主特異性を決定しているのはNod因子の種特 異的な化学修飾である。アルファルファ根粒菌(R. meliloti)(表 I 参照)や、エンドウマメまたはソラマメに感染するエンドウマメ 根粒菌(R. leguminosarum bv. viciae)のNod 因子は $\beta$ 1-4 結合をし たN-アセチル-D-グルコサミンのオリゴマーが修飾されたもので ある(13、14)。アルファルファ根粒菌(R. meliloti)の場合には硫 酸基が(13)、エンドウマメ根粒菌(R. leguminosarum bv. viciae)で はOーアセチル基と脂肪酸のアシル基が宿主特異性決定に重要 な役割を果たす(15)。拡散してきたNod因子に対し、宿主植物に

Table I. Classification of rhizobia and their synbiotic hosts

\begin{tabular}{lll}
\hline Genus & Members & Common Hosts \\
\hline Rhizobium & R. fredii & Wild Soybean (Glycine) \\
& $\begin{array}{l}\text { R. leguminosarum } \\
\text { biovar phaseoli }\end{array}$ & \\
$\quad$ biovar trifolii & Bean (Phaseolus) \\
& biovar viciae & Clover (Trifolium) \\
& R. loti & Pea (Pisum); Vetch (Vicia) \\
& R. meliloti & Trefoil (Lotus) \\
& B. japonicum & Alfalfa (Medicago) \\
\hline Bradyrhizobium & B. lupini & Soybean (Glycine) \\
& B. spp & Lupin (Lupinus) \\
& A. caulinodans & Peanut (Arachis) \\
\hline Azorhizobium & & Sesbania (Stem-nonulating) \\
\hline
\end{tabular}


tion (15), expression of genes specific for stages of infection and nodule organogenesis (the nodulins), and morphogenetic alterations such as curling of the root hairs (16).

The third level in determining host specificity occurs at the attachment of the rhizobia to the root surface. Root hairs are the target cells to which rhizobia bind and through which infection begins. When the bacterial cells are inoculated on the seedling roots, they rapidly clump at the tips of the root hair cells. Over the course of several hours, the bacteria attach in a polar (end-to-end) fashion along the sides of the root hair. Within a few days, a marked curling of the root hair tip is induced and occasionally, bacteria entrapped within the curl penetrate the root hair cell wall to form a tubular structure called the "infection thread." The invading bacteria induce proliferation of cortical cells in the root, which eventually emerge as a nodule. These nodules contain bacteria that can reduce atmospheric nitrogen into ammonia, which is assimilated by the host plant.

Studies directed at analysis of the binding between the bacteria and the host root cell have been guided, for the most part, by the "lectin recognition" hypothesis, first proposed by Krüpe (17) and later revived by Hamblin and Kent (18) and by Bohlool and Schmidt (19). According to this hypothesis, legume lectins control host specificity by interacting with saccharide components on the bacterial symbiont. It is the objective of the present review to examine this hypothesis in Rhizobiumlegume binding in three systems: i) B. japonicum and soybean; ii) $R$. leguminosarum bv. viciae and pea; and iii) $R$. trifolii and clover.

\section{B. The Clover-Rhizobium trifolii System}

The most convincing evidence in support of the "lectin recognition" hypothesis comes from detailed investigations on the clover-Rhizobium trifolii symbiosis. Dazzo and colleagues have identified a clover lectin, trifoliin A (20). This protein (subunit $M_{r} \sim 50,000$ ) is multivalent in binding to and in agglutinating $\mathrm{R}$. trifolii. There was a strong correlation between lectin binding and infectivity of the $R$. trifolii $(20,21)$. Infective strains of $R$. trifolii contain polysaccharides which are antigenically cross-reactive with those on the clover root hair cells (22). This cross-reactive antigen (CRA) binds to trifoliin A, as well as to root cells in a fashion matching the distribution of the lectin. Trifoliin A thus functions as a cross-bridge between $R$. trifolii and the root hair.

The sugar 2-deoxyglucose is a hapten inhibitor of the lectin activity of trifoliin A. It can specifically: (i) inhibit the agglutination of $R$. trifolii by the clover lectin (20); (ii) inhibit the binding of $R$. trifolii or its capsular polysaccharide (CPS) to clover root hairs (23); and (iii) dissociate trifoliin A from intact clover roots or trifoliin A-coated $R$. trifolii. An antiserum raised against CRA binds to the same or similar determinants
おいては、膜電位脱分極、感染および根粒形成の各段階に必要 な遺伝子nodulinの発現、そして根毛の変形(curling)といった形 態上の変化(16)などの応答がおこる。

宿主特異性の決定の第三段階は根粒菌の根の表面への接着 である。根毛は根粒菌が結合する標的細胞でありここから感染 が始まる。根粒菌を実生の根に接種すると、短時間のうちに根 毛細胞の先端に集まる。その後数時間で根粒菌は根毛の側面に 沿って極性をもって(端と端を接して)付着する。2、3日後には 根毛先端の顕著な変形が誘導される。そして変形した根毛に囲 まれた根粒菌が根毛細胞の細胞壁を貫通し"感染糸"と呼ばれる 管状構造を形成する。侵入した根粒菌は皮層細胞の増殖を誘導 し、根粒が出現する。この根粒の中に大気中の窒素をアンモニ アに還元できる根粒菌が含まれ、アンモニアは宿主植物によっ て同化される。

根粒菌と宿主植物の根の細胞の結合に関する研究はこれま でほとんどこの"レクチン認識"仮説をよりどころとしてきた。 この説は最初Kruppeによって提唱され(17)、のちにHamblinと Kent(18)、Bohlool とSchmidt(19) らのおかげで再び注目をあびる こととなった。この仮説によると、マメ科植物のレクチンが共 生根粒菌の糖成分と相互作用することにより宿主特異性が制御 される。この総説では、"レクチン認識"仮説を(i) ダイズとダイ ズ根粒菌(B．japonicum)、(ii)エンドウマメとエンドウマメ根粒 菌(R. leguminosarum bv. viciae)、(iii) クローバーとクローバー 根粒菌(R. trifolii)、という3種類の系で検証する。

\section{B. クローバーークローバー根粒菌の系}

"レクチン認識"仮説を支持する最も強力な証拠はクロー バーとクローバー根粒菌(R. trifolii) の共生関係の詳細な解析に よって得られる。DazzoらはクローバーからトリフォリンAとい うレクチンを同定している(20)。サブユニットの分子量が約 50,000 のこのレクチンは、クローバー根粒菌(R. trifolii) への結 合や凝集において多価性を示す。R. trifoliiに対するレクチンの 結合性と感染性には強い相関がみられた $(20 、 21) 。$ 感染性のク ローバー根粒菌(R. trifolii)菌株はクローバーの根毛細胞上にある 多糖類と抗原交差性のある多糖類を含んでいる(22)。この抗原( CRA; cross reactive antigen) はトリフォリンAに結合し、さらに トリフォリンAの局在性と一致した部位で根毛細胞に結合す る。このようにトリフォリンAはクローバー根粒菌(R. trifolii) と 根毛との間の橋渡しとして機能しているのである。

2-デオキシグルコースはトリフォリンAのレクチン活性の ハプテン阻害剂であり、i)トリフォリンAによるクローバー根粒 菌(R. trifolii) の凝集の阻害(20)、ii)クローバー根粒菌(R. trifolii) あるいはその夾膜多糖(CPS; capusular polysaccharide) のクロー バー根毛への結合の阻害(23)、iii)クローバの根やトリフォリン Aでコートした根粒菌からのトリフォリンAの解離、という3 通 りの特異的作用をもつ。抗CRA抗血清は、夾膜をもつクロー 
on the surface of encapsulated $R$. trifolii, as does trifoliin A. Fab fragments of anti-CRA blocked the agglutination of $R$. trifolii by the lectin; they also inhibited the binding of $R$. trifolii to clover root hairs (24). These experiments indicate that exposure of the CRA determinants is necessary for cross-bridging, either between two bacterial cells in trifoliin A-mediated agglutination or heterotypic adhesion of the bacteria on the clover root.

The expression of lectin receptors on the cell surface of rhizobia depends on both the culture age and the growth medium (25). This transient nature of lectin receptor expression with culture age has been correlated with Rhizobium infectivity in several Rhizobium-legume systems. For example, the number of lectin receptors on the $R$. trifolii capsule at a particular stage is directly correlated with the number of cells bound to clover root hairs (26). Chemical analyses suggest that the changes in lectin-binding capacity are due to alterations in cell surface CPS. The lipopolysaccharide of R. trifolii which express optimum lectin-binding activity showed a high level of quinovosamine (2-amino-2,6-dideoxyglucose), a hapten for lipopolysaccharide-trifoliin A agglutination activity. On the other hand, isolated CPS also showed changes in the levels of uronic acids, pyruvate, and O-acetyl substitutions with culture age. These results provide evidence that the age-dependent distribution of lectin receptors dictates the level of attachment of $R$. trifolii to clover root hairs.

Conversely, the expression of the lectin by clover roots is also dependent on the medium of the plant. Growth of the clover roots in nitrate-supplemented medium resulted in parallel reductions in levels of surface-associated trifoliin A and root hair attachment by $R$. trifolii (27).

Thus, in the specific case of clover- $R$. trifolii symbiosis, all the presently available evidence, at the correlative and phenomenological observation levels, are consistent with the "lectin recognition" hypothesis. It should also be noted that the alfalfa- $R$. meliloti interaction appears to be similar to the clover- $R$. trifolii system. It is now known that an agglutinin on alfalfa root hairs specifically binds to $R$. meliloti (28). The molecular identity of this alfalfa agglutinin and its carbohydratebinding specificity remains to be determined.

\section{The Pea-Rhizobium leguminosarum biovar viciae System}

Like many rhizobial strains, free-living $R$. leguminosarum bv. viciae cells can autoagglutinate in broth culture, shortly after the nutrient in the medium becomes limiting (29, 30). Microscopic observation revealed that fibrils are abundant in rhizobial aggregates. These fibrils are inserted polarly at the cell surface and form cross-bridges between rhizobia. Chemical analysis indicate that the major constituent of the fibrils is cellulose.

The attachment of $R$. leguminosarum bv. viciae to pea
バー根粒菌(R. trifolii)表面の、トリフォリンAが結合するのと同 一または類似の抗原決定基に結合する。トリフォリンAによる 菌の凝集を抗CRA抗体のFabフラグメントが阻害した。またこ のFabフラグメントは菌の根毛への結合も阻害した(24)。これら の結果から、トリフォリンAを介する根粒菌細胞同志の凝集や 根粒菌の根毛への異種細胞間接着にCRA抗原決定基の提示が必 要であることがわかる。

根粒菌の細胞表面にレクチン受容体が発現される時期は培 養時間や培地によって異なる(25)。レクチン受容体の一過的な 発現と根粒菌の感染性に相関が見られるシステムがいくつかあ る。例えばある段階でのクローバー根粒菌(R. trifolii) 夾膜上の レクチン受容体数は、クローバーの根毛に結合している菌数と 直接に相関している(26)。化学分析によりレクチン結合能の変 化は細胞表面CPSの変化が原因であることが示唆された。レク チン結合活性が最も高いクローバー根粒菌(R. trifolii) のリポ多 糖は、キノヴォサミン(2-アミノ-2,6- ジデオキシグルコース)の 含量が高い。このキノヴォサミンはリポ多糖ートリフォリンA 凝集活性のハプテンである。一方CPSを単離して調べると、培 養時間に対応してウロン酸、ピルビン酸塩、Oーアセチル置換 基の含量が変化していることが分かった。これらの結果は培養 時間に対応してレクチン受容体の分布が変わることが、クロー バー根粒菌(R. trifolii) のクローバー根毛への接着のレベルを決 めているということを証明している。

逆に、クローバー根におけるレクチンの発現も培地に依存 している。クローバーの根を硝酸塩を含む培地で培養すると、 表面に付着するトリフォリン Aの量と根粒菌の根毛への付着能 力が同時に低下する(27)。

それゆえクローバーとクローバー根粒菌(R. trifolii) の共生 関係という例に限っていえば、現在得られている証拠は相関関 係や現象観察のレベルにおいてすべでレクチン認識"仮説を支 持する。アルファルファとアルファルファ根粒菌(R. meliloti)の 相互作用もクローバーとクローバー根粒菌(R. trifolii) の関係に 似ている。アルファルファの根毛にある凝集素がアルファル ファ根粒菌(R. meliloti)に特異的に結合することが現在わかって いる(28)。このアルファルファの凝集素は分子としては同定さ れておらず、糖結合特異性も決まっていない。

\section{C. エンドウマメーエンドウマメ根粒菌の系}

多くの根粒菌と同じょうにエンドウマメ根粒菌 (R. leguminosarum bv.viciae)細胞は肉汁培地中の栄養素が枯渴して くるとすぐに自ら凝集することができる(29、30)。顕微鏡観察 により凝集した菌塊の中に線維構造が多量に含まれていること が明らかになった。この線維構造は細胞表面に極性をもって挿 入され、根粒菌同志で架橋を形成する。化学分析から主要構成 成分はセルロースであることがわかった。

エンドウマメ根粒菌(R. leguminosarum bv.viciae)がエンドウ 
roots appears to be mediated via a rhizobial surface protein, designated rhicadhesin (31). Rhicadhesin is a calcium-binding protein $\left(M_{r} \sim 14,000\right)$ that may have homologous counterparts in a number of rhizobial strains, including Agrobacterium and Bradyrhizobium. Purified rhicadhesin from $R$. leguminosarum bv. viciae can inhibit the attachment of rhizobia to pea root tips. This attachment is not inhibited by saccharides, including high affinity haptens (mannose, glucose and derivatives) of the pea lectin of the host plant.

Pea lectin is expressed in two isoforms, Psl-1 and Psl-2 (32). The lectin can be found on the root surface, corresponding to the susceptibility of root epidermal cells to infection by $R$. leguminosarum bv. viciae (33). However, when root cells are plasmolyzed to separate the plasma membrane from the cell wall, the lectin is found at the external surface of the plasma membrane rather than at the outer surface of the cell wall. This suggests that the pea lectin is not involved directly in attachment of the bacterial cell to the root hairs. Nevertheless, secreted pea lectin can contribute to the accumulation of rhizobia at the root hair tips to enhance nodulation.

The most striking and persuasive evidence for a role of pea lectin in root infection is the finding that transfer of the $p s l$ gene to white clover roots resulted in nodulation of the transgenic roots by $R$. leguminosarum bv. viciae (34). Normally, white clover roots release appropriate flavonoids for the induction of $R$. leguminosarum bv. viciae nod genes and signal molecules produced by the bacteria are recognized by the clover root hairs $(35,36)$. However, root hair curling is usually abnormal and infection threads are not found. Transformation of white clover roots with the pea lectin gene, however, conferred upon these roots the ability to be nodulated by $R$. leguminosarum bv. viciae. Thus, it appears that pea lectin might indeed play a key role in the normal pea- $R$. leguminosarum bv. viciae symbiosis.

\section{The Soybean-Bradyrhizobium japonicum System}

The "lectin recognition" hypothesis has fared less well in analyses of the interaction between soybean roots and its symbiont, $B$. japonicum. The available evidence fails to provide a persuasive reason to accept the notion that the plant lectin, soybean agglutinin (SBA) plays a specific and indispensable role in the recognition event. This viewpoint has been put forth succinctly by Pueppke (37). First, the binding of SBA to soybean nodulating bacteria is merely selective and not specific (i.e. SBA does bind certain strains of rhizobium that do not infect soybean roots). Second, some rhizobium strains nodulate soybean roots, but do not bind detectable amounts of SBA. Third, soybean roots that lack SBA are competent to form nodules. Finally, exogenously supplied SBA or haptens of SBA have rather unimpressive effects on the adsorption of rhizobia to soybean roots. The third and fourth points merit
マメの根に付着するときは、菌の表面にある、リカデシンと呼 ばれる蛋白質を介すると考えられる(31)。リカデシンは分子量 約14,000 のカルシウム結合性蛋白質で、Agrobacterium属や Bradyrhizobium属などいくつかの根粒菌にも相同な蛋白質があ るかもしれない。エンドウマメ根粒菌(R. leguminosarum bv. viciae)から精製したリカデシンは、菌がエンドウマメの根の先 端に付着するのを阻害する。しかしこの付着はエンドウマメレ クチンに高い親和性を示すマンノース、グルコースやその誘導 体といったハプテン糖によって阻害されない。

エンドウマメレクチンは、Psl-1 とPsl-2 という2種類のイソ 型で発現される(32)。エンドウマメレクチンは根の表面にも見 出され、エンドウマメ根粒菌(R. leguminosarum bv. viciae)が根の 表皮細胞に感染する事実と対応している(33)。しかしながら、 根の細胞の原形質膜を細胞壁から分離すると、エンドウマメレ クチンは細胞壁の外側表面よりも原形質膜の外側表面に見出さ れる(25)。このことからエンドウマメレクチンは根粒菌細胞の 根毛への付着には直接関与していないことが示唆される。それ にもかかわらず、分泌されたエンドウマメレクチンは根毛の先 端で根粒菌を集合させ根粒形成を促進する。

驚くべきことに、クローバーにエンドウマメレクチン遺伝 子psl を導入すると、形質転換したクローバーの根にエンドウマ メ根粒菌(R. leguminosarum bv.viciae)が根粒を形成した(34)。こ のことは感染にエンドウマメレクチンが関与していることを強 く示唆している。正常なクローバーの根はエンドウマメ根粒菌 (R. leguminosarum bv. viciae)にnod 遺伝子を誘導させることがて きるフラボノイドを分泌し、エンドウマメ根粒菌 (R. leguminosarum bv. viciae)から出されたシグナル分子がクロー バーの根毛によって認識される(35、36)。ただし、根毛の変形 が異常となり感染糸が見出されることはない。しかし、エンド ウマメレクチン遺伝子の導入によりクローバーの根はエンドウ マメ根粒菌(R. leguminosarum bv. viciae)による根粒形成能を獲得 する。それゆえエンドウマメとエンドウマメ根粒菌 (R. leguminosarum bv. viciae)との間の共生関係において、エンドウ マメレクチンがカギとなる役割を担っているように思われる。

\section{D. ダイズーダイズ根粒菌の系}

ダイズの根とダイズ根粒菌(B. japonicum)との相互作用は"レ クチン認識"仮説ではうまく説明できない。現在得られている知 見からは、ダイズのレクチン(SBA;ダイズ凝集素soybean agglutinin) が宿主植物と根粒菌の認識のステップにおいて特異 的かつ不可欠な働きをしているということはいえないのであ る。このことをPueppkeが簡単に整理している(37)。第一に、ダ イズに根粒を形成する根粒菌に対するSBAの結合は選択的に過 ぎず特異的ではない。すなわち、ダイズ根に感染しない根粒菌 の菌株でSBAが結合できるものがある。第二に、ダイズに根粒 を形成するがSBAの結合が検出できない根粒菌が存在する。第 三に、SBAを欠くダイズの根も根粒を形成できる。さらに、外 部からSBAを加えたり、SBAに対するハプテン糖を加えてもダ イズ根への根粒菌の吸着にはほとんど影響がみられない。な 
some elaboration.

The presence of a lectin in soybean roots has been demonstrated by isolation of a polypeptide $\left(M_{r} \sim 30,000\right)$ on the basis of its carbohydrate-binding activity (38-40). Soybean lines that were originally described as lectinless were found to express low levels of the lectin (41-43). The purified protein exhibited molecular and saccharide-binding properties similar, if not identical, to seed SBA. It was also immunologically crossreactive with antibodies raised against seed SBA. Therefore, soybean roots in general do express a lectin that binds both $\mathrm{Gal}$ and $N$-acetyl-D-galactosamine (GalNAc), same as was found for SBA.

If symbiotic rhizobia bind to soybean roots by means of SBA, addition of haptens or soluble SBA would be expected to disrupt bacterial attachment. Stacey et al. (44) found that 60 $\mathrm{mM} \mathrm{Gal}$ or $30 \mathrm{mM}$ GalNAc abolished the binding of $\mathrm{B}$. japonicum to root hairs of Glycine max (soybean) and of Glycine soya (wild soybean). More recently, however, data from two independent laboratories $(45,46)$ indicate that $B$. japonicum binding to soybean roots can be inhibited by Gal but not by GalNAc. Thus, the most glaring discrepancy between the notion of a plant lectin mediating the carbohydrate-specific recognition of bacteria and the experimental data is that, while the purified plant lectin bound both Gal and GalNAc, the latter saccharide failed to inhibit bacterial binding to the soybean cells. These results suggested that the saccharide specificity may reflect recognition components, which exhibit exquisite Gal-specific characteristics, other than the plant lectin.

Pueppke (47) also have studied the effect of exogenously supplied soluble SBA on the attachment of rhizobia to soybean roots. At a concentration of $10 \mu \mathrm{g} / \mathrm{ml}$, which saturated the Rhizobium cell, SBA resulted in $\sim 35 \%$ inhibition of bacterial binding to soybean roots. Similar observations were made on the failure of SBA to block B. japonicum adhesion to cultured soybean cells (25).

Ultrastructural studies by Tsien, Schmidt and others $(48-50)$ revealed that a $B$. japonicum cell is clearly divided into two poles: the nucleoid portion which contains the cytoplasm and the bacterial chromosome, and the reserved polymer portion which mainly contains accumulations of $\beta$ hydroxybutyrate granules and glycogen granules. The SBAbinding polysaccharides on $B$. japonicum were localized at the nucleoid end by colloidal gold-SBA labeling. Ruthenium red staining of the CPS was also localized at the nucleoid end. However, when $B$. japonicum is bound to soybean cells, fluorescently-labeled SBA stained the bacteria at a pole that was opposite from the point of attachment (51). Thus, it is not surprising that SBA, which binds to the bacteria at an end removed from the plant cell, fails to inhibit the bacterial adhesion to the plant cell.

Although it appears that SBA does not play a direct role
お、第三、第四の点についてはさらに検討する価値がある。 糖結合活性を指標にして分子量約 30,000 のポリペプチドが 単離され、ダイズ根にレクチンが存在することが示された(3840)。当初レクチンが存在しないとされていたダイズの株も低い レベルのレクチンを発現していることが見出された(41-43)。精 製された蛋白質は種子のSBAとよく似た(全く同じではなかった が) 分子としての性質および糖結合活性を示した。さらに種子 SBAに対する抗体とも免疫交差性を示した。それゆえ、種子 SBAと同じくガラクトースとN-アセチル-D-ガラクトサミンの両 方と結合するレクチンをダイズの根があまねく発現していると いえる。

もし共生根粒菌がSBAを介してダイズの根に結合するなら ば、ハプテンや可溶性のSBAを加えれば菌の付着が阻害される はずである。Stacyらはダイズ(Glycine max)やッルマメ(Glycine soya)の根毛へのダイズ根粒菌(B. japonicum)の結合が $60 \mathrm{mM}$ のガ ラクトースまたは $30 \mathrm{mM}$ の-アセチルガラクトサミンによって 消失することを見出している(44)。しかし最近になって、この 結合はガラクトースでは阻害されるが、N-アセチルガラクトサ ミンでは阻害されないという結果が2つのグループから報告され ている(45、46)。ダイズ根レクチンがガラクトースとN-アセチ ルガラクトサミンの両方に結合するにもかかわらず、N-アセチ ルガラクトサミンは根粒菌のダイズ細胞への結合を阻害しない ということは、バクテリアに対する糖特異的な認識が宿主植物 レクチンを介しておこなわれているとする考えと大きく食い 違ってしまう。よってこの糖特異性は宿主植物レクチンとは別 の、そして強いガラクトース特異性を示す認識分子の存在を示 唆するものかもしれない。

Peuppkeはまた、根粒菌のダイズ根への付着に対する可溶 性SBAの効果を調べた(47)。10 $\mathrm{g} / \mathrm{ml}$ という濃度で根粒菌に対す るSBAの結合は飽和してしまうが、ダイズ根への根粒菌の結合 は35\%程度阻害されたにすぎなかった。培養したダイズ細胞へ のダイズ根粒菌(B. japonicum)の結合も同様にSBAでは阻害され なかった。

Tsien らによる超微細構造の研究により、ダイズ根粒菌(B. japonicum)細胞ははっきりと2つの極に分かれていることがわ かった(48-50)。核様体がある極には細胞質と菌の染色体が含ま れ、もう一方の極には主に $\beta$-ヒドロキシ酪酸顆粒とグリコーゲ ン顆粒が蓄積している。金コロイド標識したSBAの結合部位か ら、SBAに結合する多糖類は核様体がある極に局在することが わかうた。ルテニウムレッド染色によりCPSも同じ極に局在す ることが見出されている。しかしながら、ダイズ根粒菌(B， japonicum)がダイズ細胞に付着しているとき、蛍光色素で標識 したSBAは菌の接着部位とは反対の極を染めた(51)。よって、 宿主植物とは接触しない側の極で菌と結合するSBAが、宿主植 物への結合を阻害しなくても不思議ではない。 SBAはダイズ根粒菌(B. japonicum)のダイズ根への結合にお 
in the attachment of B. japonicum to soybean roots, it can interact with the bacterial surface and initiate metabolic responses (52-54). A mutant of $B$. japonicum that exhibited a delay in nodulation has been isolated (55). Pretreatment of the mutant cells with soybean root exudate or SBA, however, could reverse the delay of nodulation $(53,54)$. This effect could not be mimicked using root exudates or lectins from other legume species, suggesting a high degree of specificity. Finally, soybean exudate or SBA could also enhance nodulation frequency in wild-type $B$. japonicum cells, facilitating nodule initiation at low inoculum of bacteria (53). Thus, the plant lectin clearly plays a role in the nodulation process, despite the fact that it may not directly mediate $B$. japonicum-soybean adhesion. In this respect, an analogy can be drawn between SBA in the $B$. japonicum-soybean system with the pea lectin in the $R$. leguminosarum bv. viciae-pea system.

\section{E. Saccharide-specific Binding Activities of Bradyrhizobium japonicum}

In the course of studies to analyze the Rhizobium-soybean interaction, it was observed, quite unexpectedly, that $B$. japonicum exhibit four saccharide-specific binding activities: i) adsorption to Sepharose beads covalently derivatized with lactose (Lac-Sepharose); ii) heterotypic binding to a cultured soybean cell line, SB-1 cells, originally derived from soybean roots; iii) heterotypic adhesion to soybean roots; and iv) homotypic autoagglutination (star formation). All four binding reactions can be inhibited by Gal but not by GalNAc $(46,56)$. The fact that the specificities of carbohydrate inhibition of all four assays were the same suggests that these processes may be mediated by the same component(s) and mechanism(s). Such an hypothesis is schematically illustrated in Fig. 1. The key feature of these models is that in each of the cases for heterotypic binding ( $\mathrm{i}$ - adsorption to Lac-Sepharose beads; ii - adhesion to SB-1 cells; and iii - adhesion to soybean roots), the lectin resides on the bacteria, while the other partner presents the carbohydrate ligand. In the case of homotypic binding (iv autoagglutination), the lectin, as well as its carbohydrate ligand, are found on the bacterial outer surface.

One likely candidate responsible for mediating such saccharide-specific binding is the lectin, designated BJ38 $\left(\mathrm{M}_{\mathrm{r}}\right.$ $\sim 38,000$ ), that has been purified from $B$. japonicum cells (57). BJ38 bound specifically to Gal and Gal-containing glycoconjugates. Epimeric sugars such as mannose and glucose did not show any binding. Moreover, alteration of $\mathrm{Gal}$ at the $\mathrm{C}-2$ position resulted in drastic lowering of the binding affinity, relative to Gal. For example, GalNAc exhibited 18-fold lower binding than Gal. The binding of the disaccharide Lac, on the other hand, was 13-fold higher than that of Gal. Thus, the binding of GalNAc was some 200 -fold weaker than Lac.

In all the four carbohydrate-specific binding activities
いて直接的な役割を担うことはないようであるが、菌の表面と 相互作用して代謝応答をひきおこすことができる(52-54)。根粒 形成の遅れを示すダイズ根粒菌(B. japonicum)の突然変異体がと られているが、この変異細胞をダイズ根の浸出液やSBAで前処 理すると、根粒形成の遅れが消失する $(53,54)$ 。この効果は他の マメ科の植物の根の浸出液やレクチンを用いてもみられず、高 い特異性を示すことが示唆される。また、ダイズ浸出液やSBA は野生型のダイズ根粒菌(B. japonicum)細胞の根粒形成の頻度も 増強でき、少量の菌接種による根粒形成が可能となる(53)。 よって、ダイズ根粒菌(B. japonicum)とダイズの接着に直接は介 在していないかもしれないが、ダイズレクチンは根粒形成過程 に何らかの役割をもっているに違いない。この観点から、ダイ ズ根粒菌(B. japonicum)ーダイズの系におけるSBAの役割とエン ドウマメ根粒菌(R. leguminosarum bv. viciae) 一エンドウマメの 系におけるエンドウマメレクチンの役割に類似点を見出すこと ができる。

\section{E. ダイズ根粒菌の糖特異的結合活性}

ダイズ根粒菌とダイズの相互作用を解析している過程で、 全く意外なことに、ダイズ根粒菌(B. japonicum)が4つの系で糖 特異的結合活性を示すことが観察された。その4つとは、i)ラク トースを共有結合させたセファロースビーズ-(Lac-Sepharose)へ

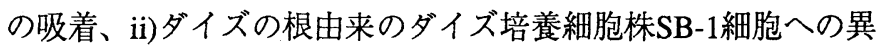
種細胞間結合、iii)ダイズ根への異種細胞間接着、iv)同種細胞間 でおこる自己凝集(star fomation)である。これらの4種類の結合反 応はすべてガラクトースで阻害を受けたがN-アセチルガラクト サミンでは阻害されなかった(46、56)。4種類のアッセイ全てに おいて阻害糖の特異性が同じであったということは、これら4つ の過程が同じ要素とメカニズムを介していることを示唆してい る。この仮説を図1に模式的に示した。このモデルでカギとなる のは、異種細胞間の結合(i)ではLac-Sepharose ビーズへの吸着、 ii)ではSB-1細胞への接着、iii)ではダイズ根への接着)においてレ クチンがバクテリア側に存在し、相手が糖リガンドを提示して いるという点である。iv)の自己凝集のような同種細胞間の結合 ではレクチンもその糖リガンドも菌体表面に見出される。

このような糖特異的結合を担っていると考えられる候補は ダイズ根粒菌(B. japonicum)から精製されたBJ38 と呼ばれる分子 量約38,000 のレクチンである(57)。BJ38はガラクトースやガラ クトースを含む複合糖鎖と特異的に結合する。ガラクトースの エピマーであるマンノースやグルコースは結合活性を全く示さ なかった。さらにガラクトースのC-2の位置に置換基をいれると 顕著な結合活性の低下がみられた。例えばN-アセチルガラクト サミンはガラクトースよりも結合活性が18倍低かった。一方、 二糖であるラクトースの結合活性はガラクトースよりも13倍高 かった。よってN-アセチルガラクトサミンの結合活性はラク トースよりも約200倍低いことになる。

調べた4種類の糖特異的結合活性のすべてにおいて、ダイ 
tested, B. japonicum bound in a polar fashion (46). Thus, any hypothesis implicating a role of BJ38 in these binding assays would require that the lectin be exposed at the surface of the bacterium where attachment occurs. A polyclonal antiserum generated against $\mathrm{BJ} 38$ was used in transmission electron microscopy and in both conventional and confocal fluorescence microscopy to localize the lectin. BJ38 was found at only one pole of the bacterium (51). The lectin appeared to be organized in a tuft-like mass, separated from the bacterial outer membrane. More importantly, BJ38 localization was coincident with the attachment site for: i) homotypic agglutination of other $B$. japonicum cells; ii) adhesion to the cultured soybean cell line, SB-1; and iii) adsorption to Lac-Sepharose beads. These results indicate that the topological distribution of $\mathrm{BJ} 38$ is consistent with a suggested role for this bacterial lectin in the polar binding of $B$. japonicum to other cells and surfaces.

The hypothesis that $\mathrm{BJ} 38$ is responsible for mediating the carbohydrate-specific binding in all four assays (see model, Fig. 1) can be demonstrated by using mutants that were defective in attachment (46). Treatment of wild-type bacteria with $N$-methyl- $N$ '-nitro- $N$-nitrosoguanidine followed by selection on the basis of reduced binding to SB-1 cells, resulted in two mutants, designated N4 and N6. Compared to wild type, these two mutants exhibited drastically diminished binding activity in all four saccharide-specific assays (46). These mutants did not show any differences, from the parental strain, in their growth rates, general morphology and motility. They also showed the same patterns of surface staining with SBA and
ズ根粒菌(B. japonicum)は極性をもった結合をした(46)。よっ て、これらの結合実験におけるBJ38の関与をいうには宿主との 接着がおこる部位にBJ38が露出されているということを示さね ばならない。BJ38に対するポリクローナル抗体を用いて透過型 電子顕微鏡や蛍光顕微鏡、共焦点レーザー顕微鏡でBJ38の局在 を観察した。BJ38はダイズ根粒菌(B. japonicum)の一方の極にの み見出だされた(51)。またBJ38はバクテリアの外膜から離れた 房のような塊にとりこまれているようにみえた。もっと重要な ことに、BJ38の局在部位は、i) ダイズ根粒菌(B. japonicum)同志 が凝集を起こすときの接着部位、ii)ダイズの培養細胞株SB-1へ の接着がおこる部位、 iii)Lac-Sepharoseビーズへの吸着における 接着部位、と一致していた。このことから、ダイズ根粒菌の極 性のある結合においてBJ38が関与していると考えても矛盾はお こらない。

図1に示している4種類の糖特異的結合全てにBJ38が関わっ ているという仮説は、接着能の突然変異体によって立証するこ とができる(46)。まず野生型のダイズ根粒菌(B. japonicum)をNメチル-N'-ニトロ-N-ニトロソグアニジンで処理し、SB-1細胞へ の結合の減弱を指標にして2種類の突然変異体N4、N6を得た。 そしてこれらの変異体を野生型と比較すると、4つの糖特異的結 合活性すべてが顕著に減弱していた(46)。しかし、増殖速度、 形態、運動性は野生型と全く変わらなかった。さらにSBAや抗 リポ多糖抗体による染色性も変わらないので、リポ多糖やCPS の合成には大きな変化はない。しかし抗BJ38抗体を用いたア

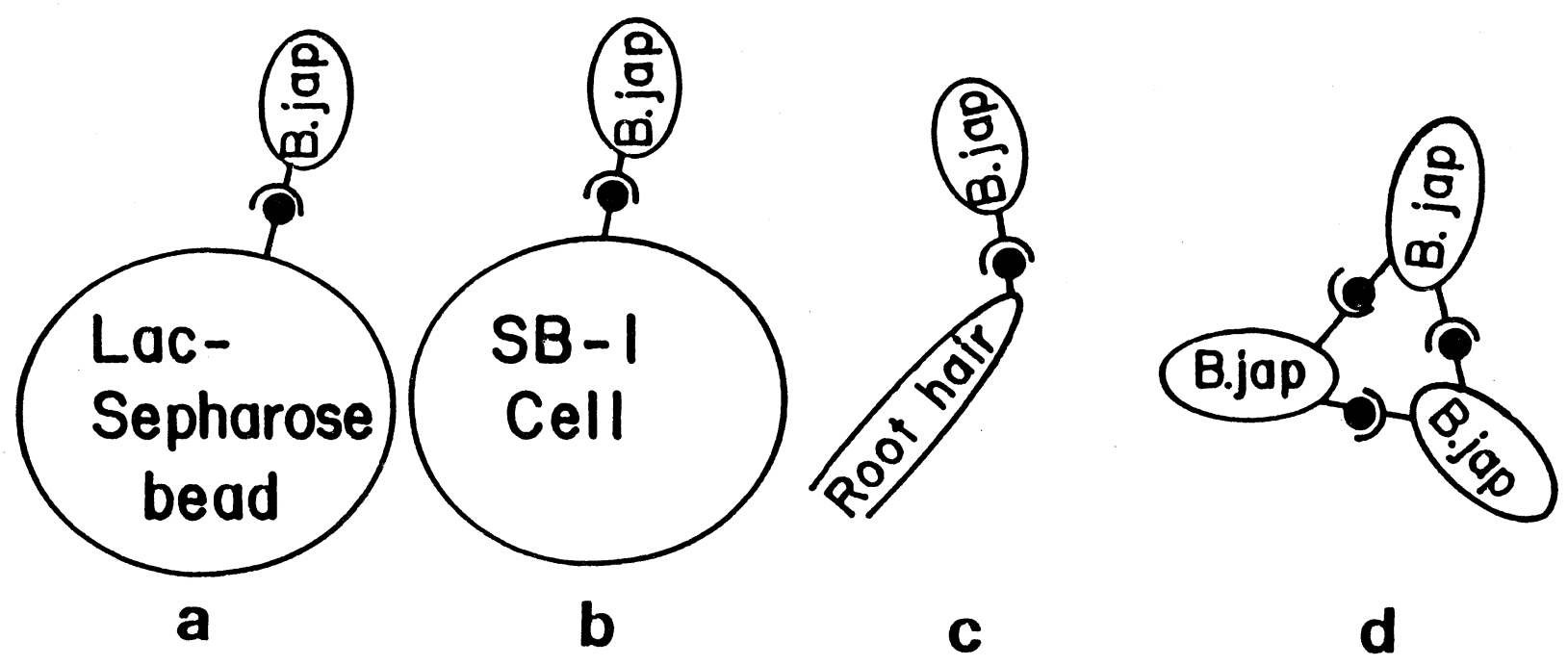

Fig. 1. Models illustrating the role of BJ38 in the binding of B. japonicum to: (a)Lac-Sepharose beads; (b)SB-1 cultured soybean cells; (c)soybean root cells; and (d)other B. japonicum, cells leading to autoagglutination. $\quad د$-BJ38; - carbohydrate ligand. 
with antibodies against lipopolysaccharides relative to the parental strain, indicating no dramatic effect on lipopolysaccharide or capsular polysaccharide synthesis. However, using both affinity isolation and immunoblotting with anti-BJ38 to quantitate the level of the lectin, BJ38 was not detectable from mutant N4. Mutant N6 produced BJ38 at a level 10-fold less than wildtype $B$. japonicum cells. More strikingly, no BJ38 could be detected at the cell surface by immunofluorescence. Thus, both the immunoblotting and immunofluorescence results are consistent with the notion that mutants N4 and N6 fail to bind to carbohydrate ligands (or beads or other cells) because they do not exhibit BJ38 at the cell surface (51).

The nodulation activity of mutants N4 and N6 was compared with the parental B. japonicum (58). Using three inoculation procedures that differed in their level of saturation and nonspecific adherence to soybean roots, the same overall conclusion was obtained: compared to wild-type, there was a drastic reduction in nodule formation in soybean seedlings inoculated with mutants N4 and N6. These results suggest that carbohydrate-specific binding, possibly mediated by $\mathrm{BJ} 38$, is an important step in the establishment of the symbiosis between soybean plants and $B$. japonicum. This, in turn, would suggest that BJ38 may be a physiologically significant ligand that binds to soybean roots.

Consistent with this notion is the finding that $\mathrm{BJ} 38$ is preferentially bound to specific regions of the root, particularly the zone of emergent root hairs. In contrast, the root cap region and the region beyond mature root hairs showed little or no binding (Ho, unpublished results). These positional effects along the soybean root are identical to those observed for the adhesion of B. japonicum cells. It has been previously demonstrated that bacteria, in general, tend to colonize at the root hair zone (59). One interpretation of this observation is that the rhizosphere surrounding this region is particularly suitable for the viability and growth of the bacteria. Such a notion cannot account, however, for the preferential binding of soluble BJ38 to the same region, inasmuch as the isolated lectin does not depend on nutrients and other factors of the environment. Thus, it seems more likely that both $B$. japonicum cells and purified BJ38 bound selectively to certain regions of the soybean root because only these regions expressed the specific ligand recognized by BJ38.

The regions of the soybean root showing preferential binding of $B$. japonicum and of BJ38 correspond precisely to those sites most susceptible to initiation of infection, as elegantly demonstrated by Bauer and coworkers using the "spot" inoculation technique $(60,61)$. Such studies have led to the conclusion that root hair deformation is one of the necessary steps in infection and nodule initiation and that the preemergent root hairs were most susceptible to deformation by the attached bacteria. Thus, three key observations correlate strongly with
フィニティー精製およびイムノブロット法で発現量を調ベる と、N4ではBJ38が検出できなかった。N6では野生型にくらべ1/ 10しか発現がみられなかった。さらに驚くべきことに、免疫蛍 光染色法を用いて調べると、BJ38は細胞表面上では全く検出さ れなかった。よってイムノブロット法と免疫蛍光染色法両方の 結果から、N4とN6は細胞表面にBJ38を発現していないために 糖リガンド(またはビーズや他の細胞) と結合できないと考えら れる(51)。

根粒形成能についてもN4、N6と野生型を比較した(58)。ダ イズの根に対する飽和度と非特異的吸着のレベルが異なる3種類 の接種法を用いても結果は同じであった。すなわち、N4とN6を 接種したダイズの実生では根粒形成が顕著に減弱した。このこ とから糖特異的結合、それも BJ38を介した結合がダイズとダイ ズ根粒菌(B. japonicum)の間の共生関係の成立において重要な一 段階であることが示唆される。また、逆にBJ38がダイズ根に結 合するための生理的に重要なりガンドであることも示唆され る。

さらに、BJ38が根の特定の領域、特に根毛が生えてくる領 域に優先的に結合することもBJ38の重要性を支持する。根冠部 や根毛が成熟し終わっている領域ではBJ38の結合はほとんど、 あるいは全くみられなかった(Hoらの未発表データ)。BJ38のダ イズの根の場所による局在の違いは、ダイズ根粒菌 (B. japonicum)の接着にみられるものと同じであった。根粒菌は根 毛領域から入りこみやすいことがこれまでに示されている (59)。一つの解橎は、この領域を囲む根圈がバクテリアの生存 成育に特に適しているというものである。しかしこの解釈では 可溶性のBJ38が同じ領域に優先的に結合することを説明できな い。というのも、単離されたレクチンの結合は栄養素やその他 の因子の影響は受けないからである。これらのことから判断し て、ダイズの根ではBJ38に認識される特異的リガンドが特定の 領域だけに発現しているために、ダイズ根粒菌(B. japonicum)と 精製BJ38の両方がこの領域に選択的に結合するという方が可能 性が高いように思われる。

ダイズ根粒菌(B. japonicum)と BJ38が優先的に結合するダイ ズの根の領域は、感染の開始に最も適した部位と完全に一致す る。このことは"スポット"接種法を用いてBauerらが見事に示し た(60、61)。この研究により、根毛の変形は感染と根粒形成の 開始に必須な一段階であること、さらに、接着した根粒菌に よって最も変形をうけやすいのはこれから生えてこようとして いる根毛であるという結論が得られた。よって次の3つの主要な 観察結果の間には強い相関がある。i)ダイズ根粒菌 (B. 
one another: i) $B$. japonicum cells preferentially bind to the young, active soybean root hairs; ii) BJ38 binds to soybean roots at sites coincident with the bacterial binding sites; and iii) the same sites were previously identified to be most susceptible to infection and nodule initiation. These correlations support the hypothesis that $\mathrm{BJ} 38$ mediates $B$. japonicum binding to soybean roots, and that the attachment is a significant step leading to successful nodulation.

\section{F. Perspectives}

The data on the $R$. trifolii-clover system (20-24) are consistent with the original "lectin recognition" hypothesis, as championed by Hamblin and Kent (18) and by Bohlool and Schmidt (19). In the pea and soybean systems, the plant lectins do not seem to have a direct role in the bacterial attachment. Although the available data do suggest that these lectins are involved in the nodulation process, the precise role that they play remains to be elucidated. On the other hand, a new and alternative view of the "lectin recognition" hypothesis, that the bacteria accounted for the lectin while the plant cells presented the carbohydrate, seems warranted, at least in the B. japonicumsoybean system $(46,51,57,58)$. This latter view puts Rhizobium-legume root cell adhesion in direct analogy with the well documented studies on the adherence of pathogenic bacteria to epithelial cell surfaces prior to infection. The molecular nature and organization of the adhesins, their saccharide specificity as lectins, and their role in infection have been reviewed elsewhere $(6,62)$. These will serve as paradigm systems upon which investigators of the Rhizobium-plant root cell system can draw for precedents and insights.

In this connection, it should be noted that the switching of the roles of lectin-carbohydrate recognition, as implicated in the new view of the "lectin recognition" hypothesis, has been documented for a single lectin molecule itself (63). Surfactant Protein A (SP-A) is an animal cell C-type lectin that can interact with both Herpes simplex virus as well as with alveolar macrophages. Recent data have demonstrated that SP-A binds to the virus-infected cells and that this binding can be inhibited by heparin. In contrast, yeast mannan fitting the specificity of the C-type carbohydrate recognition domain of SP-A did not affect the lectin's binding to the virus-infected cells. The implications of these and other results are that the carbohydrate moiety of the SP-A lectin serves as a ligand to which a heparinbinding viral protein (such as $\mathrm{gB}$ or $\mathrm{gC}$ ) can bind and that it is this carbohydrate moiety rather than the carbohydrate recognition properties of the lectin that is involved in the recognition of virus by SP-A.

From the considerations summarized above, it is apparent that Rhizobium infection of a wide variety of legumes differs from system to system. While the various systems share a great deal of similarities during the symbiosis, from the initial japonicum)は、若くて活動が活発なダイズ根毛に優先的に結合 する。ii)BJ38はダイズ根粒菌(B. japonicum)の結合部位と同じ部 位で根に結合する。iii) その部位は感染と根粒形成の開始に最も 適した部位として過去に同定されていた。これらの相関から、

BJ38はダイズ根粒菌(B. japonicum)がダイズ根へ結合するのを助 け、そうして起こる接着が根粒形成に重要なステップであると いう仮説が支持される。

\section{F. 今後の展望}

$$
\text { クローバー根粒菌(R. trifolii) 一クローバーの系(20-24)に }
$$

は、Hamblin とKent(18)、Bohlovlと Schmidt(19)が提唱した本来 の"レクチン認識"仮説があてはまる。エンドウマメとダイズの 系では、植物レクチンは根粒菌の接着に直接は関与していない ように思われる。現在得られている知見から、植物レクチンが 根粒形成過程に関わっていることは示唆されるが、本当の役割 はまだ明らかになっていない。一方、ダイズ根粒菌 (B. japonicum)ーダイズの系においては、"レクチン認識"仮説の新し いとらえ方、すなわち、バクテリア側がレクチンを、宿主植物 側が糖を提示するという見方ができると思われる(46、51、57、 58)。これにより、根粒菌とマメ科植物の根の接着と、病原性バ クテリアが感染前におこす上皮細胞表面への接着を直接比較し

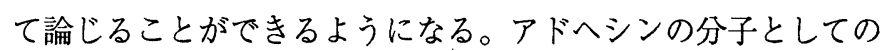
性質や構造、レクチンとしての糖結合特異性、そして感染にお ける役割は他の総説を参照されたい(6、62)。根粒菌一植物の根 の細胞の系の研究者にとってよい模範となるであろう。

これに関連して、"レクチン認識"仮説の新たなとらえ方で ある、「レクチンと糖の認識における役割交換」が、一つのレ クチン分子においてもおこりうることを知っておくとよいだろ う(63)。界面活性蛋白質A( SP-A; Surfactant Protein A) は単純へ ルペスウイルスと肺胞マクロファージの両方と相互作用できる C-タイプの動物レクチンである。最近、SP-Aがウイルスに感染 した細胞に結合し、この結合がヘパリンによって阻害できるこ とが示された。その一方でSP-AのC-タイプ糖認識ドメインの特 異性をみたす酵母のマンナンはウイルス感染細胞へのSP-Aの結 合を阻害しなかった。他の実験結果も併せてみると、SP-Aレク チンの糖鎖部分がgBやgCのようなへパリン結合性ウイルス蛋白 質のリガンドとして機能し、レクチンとしての性質よりもSP-A の糖鎖そのものがウイルスの認識に関わっていると考えられ る。

上にまとめた考察から、様々なマメ科の植物への根粒菌の 感染は系によって異なることは明らかである。共生の成立にお いて、すなわち、最初の感染の誘導から窒素固定という最終的 な生理的応答に至るまで互いに類似した点が多々あるけれど 
induction of infection to the final physiological responses in nitrogen fixation, individual steps may be mediated via different compounds and mechanisms.

\section{Acknowledgements}

The work carried out in the authors' laboratories has been supported by grant GM-45200 from the National Institutes of Health.
も、各々の段階は異なった物質やメカニズムを介していると考 えられる。

帝京大学・薬学部・生物化学

荒田 洋一郎訳

\section{References}

1. Edelman, G.M., and Crossin, K.L. (1991) Ann. Rev. Biochem. 60, 155-190

2. Takeichi, M. (1990) Ann. Rev. Biochem. 59, 237-252

3. Hynes, R.O. (1992) Cell 69, 11-25

4. Aruffo, A. (1992) Trends Glycosci. Glycotechnol. 4, 146-151

5. Miller, D.J., Macek, M.B., and Shur, B.D. (1992) Nature 357, 589-593

6. Ofek, I., and Sharon, N. (1990) Curr. Topics Microbiol. Immunol. 151, 91-113

7. Bauer, W.D. (1981) Ann. Rev. Plant Physiol. 32, 407-449

8. Brewin, N.J. (1991) Ann. Rev. Cell Biol. 7, 191-226

9. Sanchez, F., Padilla, J.E., Perez, H., and Lara, M. (1991) Ann. Rev. Plant Physiol. Mol. Biol. 42, 507-528

10. Fisher, R.F., and Long, S.R. (1992) Nature 357, 655-660

11. Maxwell, C.A., and Phillips, D.A. (1990) Plant Physiol. 93, 1552-1558

12. Long, S.R. (1989) Cell 56, 203-214

13. Lerouge, P., Roche, P., Faucher, C., Maillet, F., Truchet, G., Prome, J.C., and Denarie, J. (1990) Nature 344, 781-784

14. Spaink, H.P., Sheely, D.M., Van Brussel, A.A.N., Glushka, J., York, W.S., Tak, T., Geiger, O., Kennedy, E.P., Reinhold, V.N., and Lugtenberg, B.J.J. (1991) Nature 354, 125-130

15. Ehrhardt, D.W., Atkinson, E.M., and Long, S.R. (1992) Science 256, 998-1000

16. Truchet, G., Roche, P. Lerouge, P., Vasse, J., Camut, S., DeBilly, F., Prome, J.C., and Denarie, J. (1991) Nature 351, 670-673

17. Krüpe, M (1956) Blutgruppenspezifische Pflanzliche Eiweisskörper (Phytagglutine). Ferdinand Enke, Sttugart, pp.131

18. Hamblin, J. and Kent, S.P. (1973) Nature New Biol. 254, 28-30

19. Bohlool, B.B. and Schmidt, E.L. (1974) Science 185, 269-271

20. Dazzo, F.B., Yanke, W.E., and Brill, W.J. (1978) Biochim. Biophys. Acta 539, 276-286

21. Dazzo, F.B. (1981) J. Supramol. Struct. Cell Biochem. 16, 29-41

22. Dazzo, F.B., and Hubbell, D.H. (1975) Appl. Microbiol. 30, 1017-1033

23. Dazzo, F.B., and Brill, W.J. (1977) Appl. Environ. Microbiol. 33, 132-136

24. Dazzo, F.B. and Brill, W.J. (1979) J. Bacteriol. 137, 1362-1373

25. Ho, S.C., and Kijne, J.W. (1991) in: Lectin Reviews, (Kilpatrick, D.C., Van Driessche, E., \& Bøg-Hansen, T.C., eds. ) Vol. 1, pp. 171-181, Sigma, St. Louis, MO, USA.

26. Hrabak, E.M., Urbano, M.R., and Dazzo, F.B. (1981) J. Bacteriol. 148, 697-711

27. Dazzo, F.B., and Brill, W.J. (1978) Plant Physiol. 62, 18-21

28. Paau, A.S., Leps, W.T., and Brill, W.J. (1981) Science 213, 1513-1515

29. Smit, G., Kijne, J.W., and Lugtenberg, B.J.J. (1986) J. Bacteriol. 168, 821-827

30. Smit, G., Kijne, J.W., and Lugtenberg, B.J.J. (1987) J. Bacteriol. 169, 4294-4301

31. Smit, G., Logman, G.J.J., Boerringter, M.E.T.I., Kijne, J.W., and Lugtenberg, B.J.J. (1989) J. Bacteriol. 171, 4054-4062

32. Diaz, C.L., Hosselet, M, Log, G.J.J., Van Driessche, E., Lugtenberg, B.J.J., and Kijne, J.W. (1990) Planta 181, 451-461

33. Diaz, C.L., van Spronsen, P.C., Bakhuizen, R., Logman, G.J.J., Lugtenberg, B.J.J., and Kijne, J.W. (1986) Planta 168, 350-359

34. Diaz, C.L., Melchers, L.S., Hooykaas, P.J.J., Lugtenberg, B.J.J., and Kijne, J.W. (1989) Nature 338, 579-581

35. Spaink, H.P., Wijffelman, C.A., Pees, E., Okkar, R.J.H., and Lugtenberg, B.J.J. (1987) Nature 328, 337-340

36. Spaink, H.P., Okkar, R.J.H., Wijffelman, C.A., Pees, E., and Lugtenberg, B.J.J. (1987) Plant Mol. Biol. 9, 27-39

37. Pueppke, S.G. (1983) in: Chemical Taxonomy, Molecular Biology and Function of Plant Lectins, (Goldstein, I.J. \& Etzler, M.E., eds.) pp. 225-236, Alan R. Liss, New York, NY, USA.

38. Gade, W., Jack, M.A., Dahl, J.B., Schmidt, E.L., and Wold, F. (1981) J. Biol. Chem. 256, 12905-12910

39. Gade, W., and Schmidt, E.L. (1983) Planta 158, 108-110

40. Malek-Hedayat, S., Meiners, S.A., Metcalf, T.N., Schindler, M. and Wang, J.L. (1987) J. Biol. Chem. 262, 7825-7830

41. Goldberg, R.B., Hoschek, G., and Vodkin, L.O. (1983) Cell 33, 465-475

42. Vodkin, L.O., Rhodes, P.R., and Goldberg, R.B. (1983) Cell 34, 1023-1031

43. Vodkin, L.O., and Raikhel, N.V. (1986) Plant Physiol. 81, 558-565

44. Stacey, G., Paau, A.S., and Brill, W.J. (1980) Plant Physiol. 66, 609-614

45. Vesper, S.J. and Bauer, W.D. (1985) Symbiosis 1, 139-162

46. Ho, S.C., Wang, J.L., and Schindler, M. (1990) J. Cell Biol. 111, 1631-1638

47. Pueppke, S.G. (1984) Plant Physiol. 75, 924-928

48. Tsien, H.C., and Schmidt, E.L. (1977) Can. J. Microbiol. 23, 1274-1284

49. Bohlool, B.B., and Schmidt, E.L. (1976) J. Bacteriol. 125, 1188-1194

50. Bal, A.K., Shantharam, S., and Ratnam, S. (1978) J. Bacteriol. 133, 1393-1400 
51. Loh, J.T., Ho, S.C., deFeijter, A.W., Wang, J.L., and Schindler, M. (1993) Proc. Natl. Acad. Sci. USA 90, 3033-3037

52. Halverson, L.J., and Stacey, G. (1985) Plant Physiol. 77, 621-625

53. Halverson, L.J., and Stacey, G. (1986) Appl. Environ. Microbiol. 51, 753-760

54. Halverson, L.J., and Stacey, G. (1984) Plant Physiol. 74, 84-89

55. Stacey, G., Paau, A.S., Noel, K.D., Maier, R.J., Silver, L.E., and Brill, W.J. (1982) Arch. Microbiol. 132, $219-224$

56. Ho, S.C., Ye, W., Schindler, M., and Wang, J.L. (1988) J. Bacteriol. 170, 3882-3890

57. Ho, S.C., Schindler, M., and Wang, J.L. (1990) J. Cell Biol. 111, 1639-1643

58. Ho, S.C. (1992) Symbiosis 14, 131-141

59. Foster, R.C., and Bowen, G.D. (1982) in: Phytopathogenic Procaryotes, (Mount, M.S. \& Lacy, G.H., eds.) Vol. 1, pp. 159-185, Academic Press, New York, NY, USA.

60. Bhuvaneswari, T.V., Turgeon, B.G., and Bauer, W.D. (1980) Plant Physiol. 66, 1027-1031

61. Calvert, H.E., Pence, M.K., Pierce, M., Malik, N.S.A., and Bauer, W.D. (1984) Can. J. Bot. 62, 2375-2384

62. Jann, K., and Hoschüzky, H. (1990) Curr. Topics Microbiol. Immunol. 151, 55-70

63. van Iwaarden, J.F., van Strijp, J.A.G., Visser, H., Haagsman, H.P., Verhoef, J., and van Golde, L.M.G. (1992) J. Biol. Chem. 267, 2503925043

Received on June 8, 1993; accepted on July 12, 1993

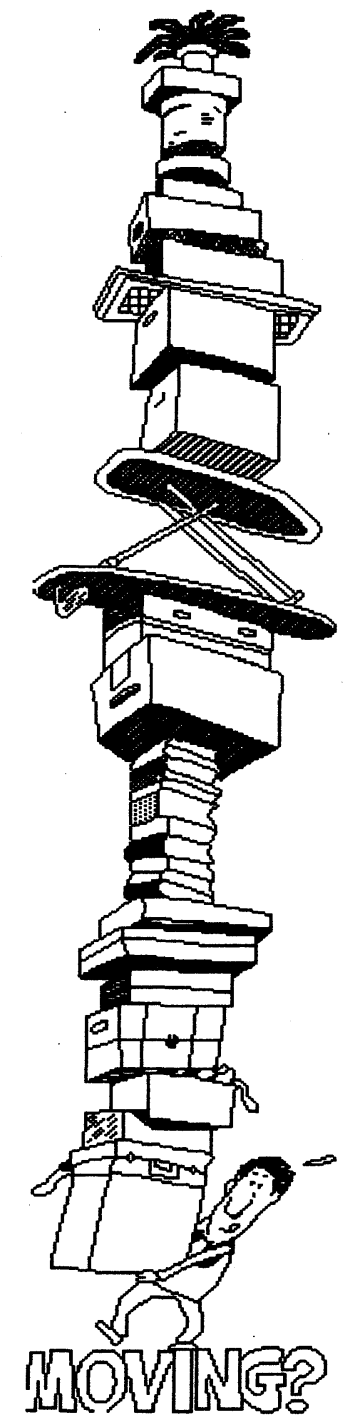

